\title{
Sublittoral hard substrate communities of the southern Delta area, SW Netherlands
}

\author{
M.J. de Kluijver \\ Institute of Taxonomic Zoology, University of Amsterdam, P.O. Box 4766, 1009 AT Amsterdam, \\ The Netherlands; SBNO; P.O. Box 16915, 1001 RK Amsterdam, The Netherlands
}

Keywords: sublittoral, hard substrate, communities, environmental parameters, Netherlands

\begin{abstract}
During 1985 and 1986, sublittoral communities on hard substrates in the southern Delta area, SW Netherlands, were investigated at 79 stations. The stations were distributed over 20 localities situated in the saline Lake Grevelingen, the Oosterschelde estuary and the SE North Sea. The percentage cover of all sessile organisms were estimated using quadrat sampling techniques; data were processed using cluster analysis. The stations were characterized by the assessment of the most important environmental parameters: available light, hydrodynamics and sediment characteristics. Eight sublittoral communities on hard substrates are described by characteristic and dominant species. Three communities are subdivided into variants on account of differences in abundance of the dominant species. This quantitative approach leads to reproduceable results.
\end{abstract}

\section{Résumé}

En 1985 et 1986, les communautés sublittorales sur substrats durs ont été étudiées dans 79 stations de la partie méridionale de la zone du Delta (SO des Pays-Bas). Ces stations ont été choisies dans une vingtaine de localités du lac salé Grevelingen, de l'estuaire d'Oosterschelde, et de la partie SE de la Mer du Nord. Le pourcentage de tous les organismes sessiles a été estimé par utilisation de techniques d'échantillonnage sur surfaces carrées; les données ont été traitées par "cluster analysis". Les stations sont caractérisées par évaluation des paramètres les plus importants du milieu: lumière accessible, hydrodynamique, particularités du sédiment. Huit communautés sublittorales sur substrats durs sont décrites en termes d'espèces caractéristiques et dominantes. Pour trois de ces communautés on reconnaît des variantes, compte tenu de différences dans l'abondance des espèces dominantes. Cette approche quantitative aboutit à des résultats reproductibles.

\section{Introduction}

Recent pollution and human maritime manipulations are characteristic for the pressure the marine ecosystem is subjected to in the SW Netherlands. Perkins (1974) already mentioned the importance of estuaries and coastal waters for commercial fisheries and other types of exploitation of the sea. The contribution of hard substrate benthic communities to this ecosystem is certainly not to be underestimated. Although the total surface of hard substrate is only a small fraction of the total sublittoral bottom surface in the Oosterschelde estuary, the hard substrate sessile animals stand for $32.7 \%$ of the total benthic biomass (Leewis \& Waardenburg, in prep.). To use these hard substrate communities for ecological monitoring, a reproduceable description of both the communities and the environmental parameters must be available. Reproducibility demands some conditions of the investigation. In the first place, the communities must be studied as a whole. Many investigations on marine hard substrate communities only deal with a particular taxonomic group, for example algae (Den Hartog, 1959; Nienhuis, 1980; Coppejans, 1980), sponges (Pansini et al., 1977), Polychaeta (Bianchi \& Morri, 1985) and Octocorallia (Weinberg, 1978b). Second, the data must be quantified as much as possible. Studies on sublittoral hard substrate communities as a whole are often qualitative (Stephenson \& Stephenson, 1972; Hiscock \& Hiscock, 1980; Könnecker \& Keegan, 1983). The main benefit of quan- 


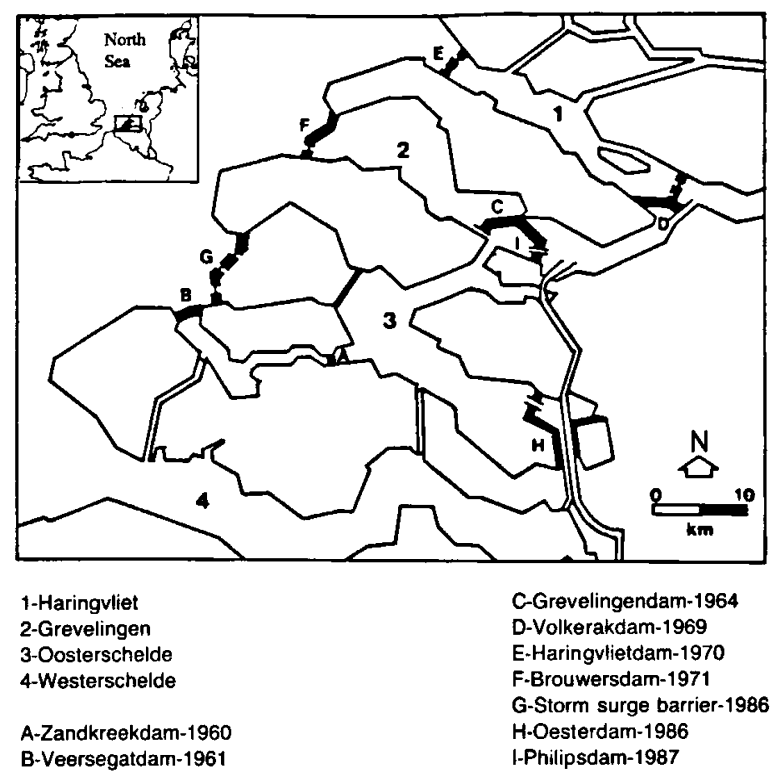

Fig. 1. Map of the study area with dates of the main closure works of the "Delta Plan".

titative studies is, that it becomes possible to describe communities by means of characteristic species (common species, but restricted to just one community) and dominant species (occurring in more communities, but abundant in just a few communities). Examples of quantitative studies on marine hard substrate communities are: Gislen (1930), Van Soest \& Weinberg (1981), Kaandorp (1986), De Kluijver (1986), De Kluijver et al. (in prep.) and Leewis \& Waardenburg (in prep.).

Although all hard substrate in the Netherlands is artificial, the southern Delta area is suitable for the study of the structure of sublittoral communities in relation to the environmental parameters. In this area a diverse scale of different habitats is availabe (Anonymous, 1982). After the disastrous inundations of 1953 it was decided to close off the main estuaries (Delta Plan). The situation and dates of the main closure works are shown in fig. 1 . In 1971 the Grevelingen estuary was closed and became a tideless salt water lake with a water area of $108 \mathrm{~km}^{2}$. Morphometrical, hydrochemical and hydrophysical data of this lake are enumerated by Bannink et al. (1984). To the south, in the Oosterschelde estuary the original (uninfluenced) structure of sublittoral communities of the estuaries can be investigat- ed. Although intended to be closed off too, it was decided later, owing to the efforts of environmental pressure groups, to protect the hinterland by a storm surge barrier with open floodgates, that can be closed with steel slides during extreme spring tides and bad weather conditions (Leemans \& Geers, 1983). The artificial opening has been restricted to $14,000 \mathrm{~m}^{2}$. The natural opening of the mouth of the estuary amounted to $80,000 \mathrm{~m}^{2}$, which caused a tidal range of $3.7 \mathrm{~m}$ in the eastern part. To ensure a tidal range of $2.75 \mathrm{~m}$ after completion (October 1986) of the storm surge barrier, two compartmentalisation-dams were constructed (Oesterdam, October 1986, and Philipsdam, April 1987). The surface area of the tidal region is reduced from $400 \mathrm{~km}^{2}$ to $310 \mathrm{~km}^{2}$, implying a reduction of the volume from $1230.10^{6} \mathrm{~m}^{3}$ to $820.10^{6} \mathrm{~m}^{3}$. This caused a reduction of the stream velocity leading to changes in the other environmental parameters (sediment load, submarine daylight and salinity).

In this paper the results are presented of the study of the original communities of the Oosterschelde estuary, the communities of the tideless Lake Grevelingen, and the coastal communities of the neighbouring North Sea dikes in the southern Delta area. The environmental parameters are quantified as much as possible. In forthcoming papers changes in species composition and community structures, caused by changes in the environmental parameters, will be discussed.

\section{Materials and methods}

During the years of 1985 and 198679 stations at 20 localities were investigated along the dikes of the southern Delta area (fig. 2). Not only the sublittoral hard substrate communities were quantified, but also the most important environmental parameters.

\section{Sampling}

The communities were sampled using the "Individual Counting and Cover Estimate" (ICCE) method described by Weinberg (1981). The percentages cover of the vertical projection of all sessile organisms were estimated, using a quadrat of $32 \times$ 


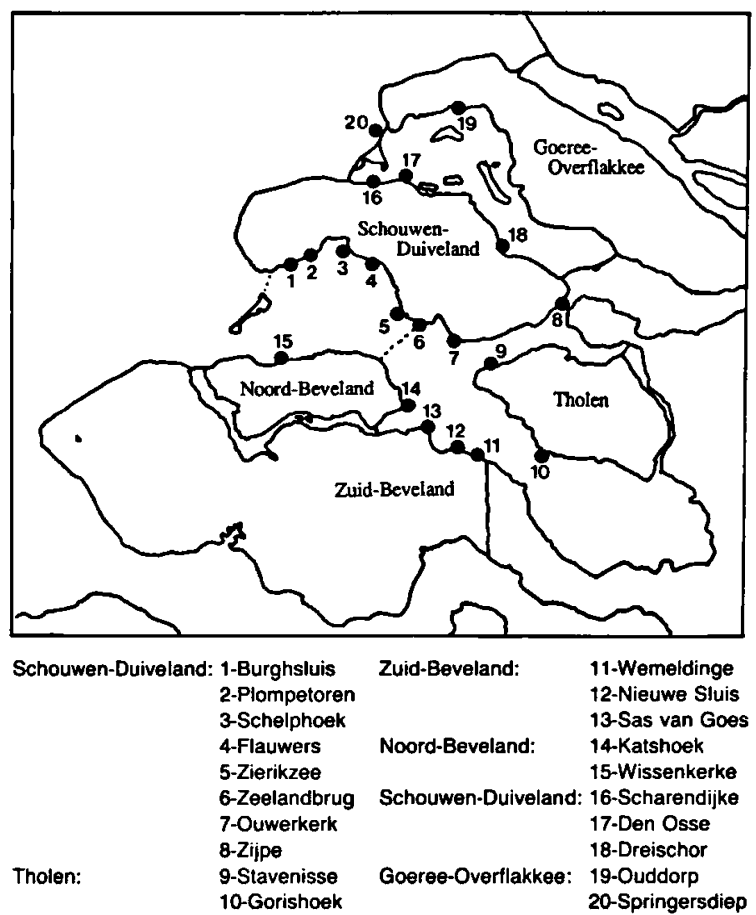

Fig. 2. Map of the study area showing the localities.

$32 \mathrm{~cm}$. In order to obtain comparable data the organisms were not counted, but only percentages cover were estimated. Underwater it was not possible to quantify the different species of tubicolous organisms. These species belong to different taxa of Crustacea (Amphipoda) and Polychaeta (Terebellidae and Spionidae). In the results these species are taken together. Because of the poor visibility of the water, vagile organisms were not included. In both years and during different seasons, the same localities were sampled.

\section{Minimal area}

In order to take a representative sample, usually 3 to 4 quadrats were sampled at each station. The minimal area was determined for 3 different communities (De Kluijver, 1986), using the program MINAR (Kaandorp, 1986) with logarithmically transformed data. In fig. 3 the curve for Station 34, Ouddorp, depth $9.0 \mathrm{~m}$ (number of species, $\mathrm{n}=27$ ), is shown. Weinberg (1978a) suggested a similarity level of 0.70 at which the minimal area is reached. This level is reached at this station within 1 quadrat

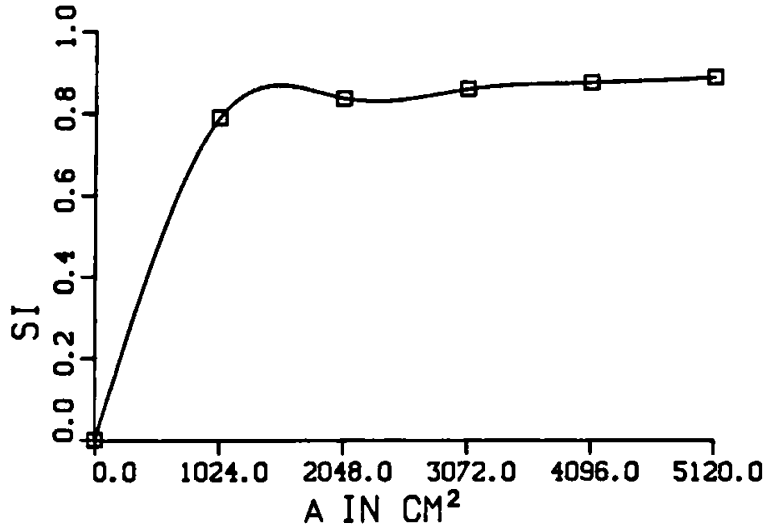

Fig. 3. Bray-Curtis coefficient (SI) as a function of the sampled surface (A) for Station 34 (Ouddorp-9.0 $\mathrm{m}$ depth).

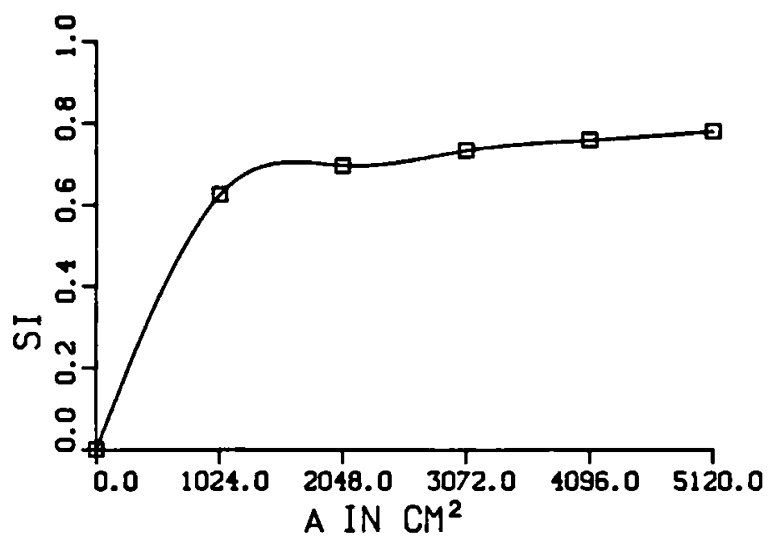

Fig. 4. Bray-Curtis coefficient (SI) as a function of the sampled surface (A) for Station 36 (Schelphoek - $10.5 \mathrm{~m}$ depth).

$\left(10.2 \mathrm{dm}^{2}\right)$. In fig. 4 the curve for Station 36 , Schelphoek, depth $10.5 \mathrm{~m}(\mathrm{n}=21)$, is shown. The 0.70 similarity level is reached within 3 quadrats $\left(30.7 \mathrm{dm}^{2}\right)$. Fig. 5 shows the curve for Station 40 , Wemeldinge, depth $8.0 \mathrm{~m}(\mathrm{n}=23)$. Again the 0.70 level is reached within 1 quadrat. In the southern Delta area the mosaic distribution of the components of the communities appears to be very homogeneous compared to the sublittoral communities of the Atlantic coasts, where a minimal area of $150 \mathrm{dm}^{2}$ was found (De Kluijver et al., in prep.).

\section{Environmental parameters}

In a diverse area as the southern Delta area, with a saline lake, an estuary and the open North Sea, it 


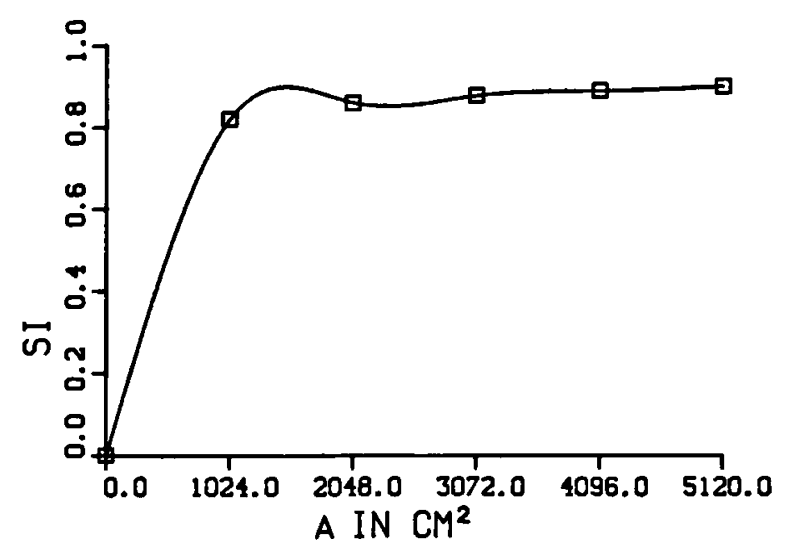

Fig. 5. Bray-Curtis coefficient (SI) as a function of the sampled surface (A) for Station 40 (Wemeldinge-8.0 $\mathrm{m}$ depth).

is necessary to quantify the environmental parameters as much as possible. The following parameters were assessed:

- Submarine daylight

Measurements were carried out using a relative "Underwater Hemispherical Irradiance Meter" (UHIM) described by Weinberg (1979). The spectral sensitivity of this meter (peak value $480 \mathrm{~nm}$; band-width $60 \mathrm{~nm}$ ) roughly corresponds to the transmission characteristics of the water. From the light intensity in midwater, the vertical extinction coefficient $\left(k\right.$ in $\mathrm{m}^{-1}$ ) was calculated. From the measurements at the station and the corresponding intensity in midwater, the station coefficient (sc in \%) was obtained. Measurements were performed during the turn of the tide.

\section{- Water movement}

The exposure of the sublittoral communities to water movement was measured by relating the erosion of gypsum blocks to the rate of exposure. The erosion value is expressed as the weight loss of the gypsum blocks (g.hour ${ }^{-1}$ ) during a lunar day (24.45 hours). A description of this method, including a mathematical framework, is given by De Kluijver \& Kaandorp (in prep.).

\section{- Sediment load}

Because it was not possible to quantify the sediment load, the amount was estimated and expressed as one of 6 classes ( - : no sediment available, ++++ : all bare substrate covered with sediment). In order to get the sediment characteristics the top cm layer was investigated at nearly all localities. The sediment samples were sieved through 6 graded sieves (2.9-0.09 mm). The sediment characteristics are expressed as the proportional contribution of the dry weight of the different sieved fractions. The contribution of the various fractions were analyzed using the computer programs CLUSTAN1C2 (Wishart, 1978) and SRTORD (Kaandorp, 1986; in prep.).

\section{- Temperature}

Temperature was measured with a modified mercury thermometer (Weinberg, 1979). Both the surface (Topp) and bottom temperatures (Tstat) were measured at each station.

\section{Description of the stations}

In table 1 the characteristics are given of the stations sampled. The depth of a station is given in relation to NAP (Amsterdam Ordnance Datum, approximately Mean Sea Level).

Sublittoral hard substrate communities are composed of different structural layers. In this area a distinguishable top layer (TL) might be developed by thalli of the brown algae Laminaria saccharina and Sargassum muticum. A middle layer (ML) is formed by organisms which are erect on the substrate, but do not belong to the top layer. The encrusting layer (EL) consists of organisms adhering to the substrate.

\section{Cluster analysis and inverse analysis}

For the cluster analysis the percentages cover of all sessile species of the quadrats of a station were averaged. This yielded a data table of 79 stations and 99 species. Before analysis all data were logarithmically transformed. The cluster analysis was carried out using the computer program CLUSTAN1C2 (Wishart, 1978). As suggested by Kaandorp (in prep.) the Average Linkage method (Sokal \& Michener, 1958) was used, combined with the Bray-Curtis coefficient. The combination of these algorithm and coefficient is widely applied in marine ecology and leads to reproduceable results. 
Table 1. Description of the sampled stations. (For abbreviations see p. 144).

\begin{tabular}{|c|c|c|c|c|c|c|c|c|c|}
\hline Station: & Depth: & Date: & Slope: & Oriert: & Topp: & Tant: & Sediment: & Area: & Cluster: \\
\hline 01-Schelphoek & 07.5 & $25-06-85$ & 39.0 & 246.0 & 15.5 & 15.4 & + & 4500 & $\mathbf{A}$ \\
\hline 02-Schelphoek & 02.5 & $06-07-85$ & 47.5 & 232.5 & 18.4 & 18.3 & $+++t$ & 3600 & D \\
\hline 03-Zierikzee & 02.8 & $13-07-85$ & 33.8 & 250.0 & 20.5 & 18.7 & \pm & 4096 & $\mathbf{E}$ \\
\hline 04-Zierikzee & 11.7 & $14-07-85$ & 48.8 & 302.5 & 20.5 & 19.0 & + & 4096 & B1 \\
\hline OS-Wemeldinge & 05.1 & $20-07-85$ & 56.3 & 067.5 & 19.5 & 19.2 & $H$ & 4096 & B1 \\
\hline 06-Wemeldinge & 05.2 & $21-07-85$ & 52.5 & 107.5 & 19.2 & 19.0 & + & 4096 & B1 \\
\hline 07-Scharendijke & 03.5 & $27-07-85$ & 56.3 & 016.3 & 19.5 & 18.5 & + & 4096 & H \\
\hline 08-Sas van Goes & 09.0 & $27-07-85$ & 42.5 & 060.0 & 20.5 & 19.0 & + & 4096 & B1 \\
\hline 09-Zierikzee & 03.8 & $28-07-85$ & 67.5 & 292.5 & 19.0 & 19.0 & _- & 4096 & B1 \\
\hline 10-Zuidbout & 10.2 & $28-07-85$ & 43.8 & 190.0 & 19.0 & 19.0 & ++ & 4096 & B4 \\
\hline 11-Scharendijke & 15.0 & $10-08-85$ & 24.8 & 127.5 & 17.2 & 17.0 & +4 & 4096 & I \\
\hline 12-Scharendijke & 05.9 & $11-08-85$ & 31.0 & 110.0 & 18.9 & 17.0 & + & 4096 & H \\
\hline 13-Zuidbout & $\infty 2.7$ & $11-08-85$ & 26.3 & 120.0 & 17.8 & 17.5 & \pm & 4096 & E \\
\hline 14-Nieuwe Sluis & 03.3 & $18-08-85$ & 15.5 & 060.0 & 19.0 & 17.5 & + & 4096 & E \\
\hline 15-Zierikzee & 16.1 & $18-08-85$ & 17.5 & 280.0 & 18.0 & & ++ & 2048 & B4 \\
\hline 16-Dreischor & 08.3 & $2408-85$ & 36.3 & 055.0 & 17.5 & 17.5 & \pm & 4096 & $I$ \\
\hline 17-Zijpe & 05.0 & $25-08-85$ & 47.5 & 105.0 & 17.2 & 17.2 & - & 2048 & B2 \\
\hline 18-Nieuwe Sluis & 13.0 & $25-08-85$ & 32.5 & 080.0 & 18.0 & 17.5 & \pm & 4096 & B3 \\
\hline 19-Sas van Goes & 04.0 & $26-08-85$ & 20.0 & 320.0 & 17.5 & 17.2 & + & 2048 & $\mathbf{E}$ \\
\hline 20-Wissenkerke & 10.7 & $07-09-85$ & 28.8 & 360.0 & 17.0 & 16.5 & $H$ & 4096 & $\mathbf{A}$ \\
\hline 21-Burghsluis & 04.0 & $08-09-85$ & 56.3 & 137.5 & 16.0 & 16.0 & + & 4096 & $\mathbf{A}$ \\
\hline 22-Stavenisse & 09.8 & $14-09-85$ & 37.5 & 258.8 & 16.5 & 16.0 & + & 4096 & B4 \\
\hline 23-Gorishoek & 04.6 & $15-09-85$ & 45.0 & 270.0 & 16.0 & & $H$ & 1024 & B1 \\
\hline 24-Dreischor & 03.0 & $15-09-85$ & 48.8 & 080.0 & 16.0 & 15.8 & \pm & 4096 & H \\
\hline 25-Katshoek & 09.3 & $22-09-85$ & 45.0 & 310.0 & 16.3 & 16.2 & \pm & 2048 & B4 \\
\hline 26-Wemeldinge & 10.5 & $22-09-85$ & 60.0 & 075.0 & 17.2 & 16.5 & \pm & 4096 & B3 \\
\hline 27-Flauwers & 11.5 & 29-09-85 & 47.5 & 226.7 & 17.5 & 17.0 & + & 4096 & B3 \\
\hline 28-Flauwers & 07.5 & $12-10-85$ & 43.8 & 202.5 & 16.1 & 15.4 & + & 4096 & B3 \\
\hline 29-Den Osse & 12.5 & $12-10-85$ & 41.7 & 310.0 & 15.5 & 15.4 & \pm & 3072 & I \\
\hline 30-Schelphoelr & 15.0 & $13-10-85$ & 38.8 & 200.0 & 16.2 & 15.0 & - & 4096 & $\mathbf{A}$ \\
\hline 31-Den Osse & 06.0 & $13-10-85$ & 35.0 & 310.0 & 15.1 & 15.1 & - & 2048 & H \\
\hline 32-Burghsluis & 08.3 & $19-10-85$ & 33.8 & 155.0 & 15.0 & 14.8 & - & 4096 & $\mathbf{A}$ \\
\hline 33-Burghsluis & 16.5 & $20-10-85$ & 45.0 & 135.0 & 14.8 & 14.5 & \pm & 4096 & $\mathbf{A}$ \\
\hline 34-Ouddorp & 09.0 & $27-04-86$ & 15.0 & 166.7 & 11.5 & 08.0 & \pm & 10240 & I \\
\hline 35-Burghsluis & 07.0 & $28-04-86$ & 30.0 & 150.0 & 08.3 & 07.0 & $H$ & 4096 & C \\
\hline 36-Schelphoek & 10.5 & $03-05-86$ & 43.8 & 230.0 & 10.4 & & +++ & 10240 & $\mathbf{A}$ \\
\hline 37-Flauwers & 10.0 & $05-05-86$ & 50.0 & 210.0 & & & + & 4096 & B3 \\
\hline 38-Zierikzee & 03.5 & $14-05-86$ & 40.0 & 300.0 & 11.5 & 10.8 & + & 4096 & $\mathbf{E}$ \\
\hline 39-Dreischor & 07.5 & $1605-86$ & 50.0 & 070.0 & 14.8 & 129 & - & 4096 & $\mathbf{I}$ \\
\hline 40-Wemeldinge & $\mathbf{0 8 . 0}$ & $17-05-86$ & 60.0 & 070.0 & 12.6 & 12.0 & + & 10240 & B3 \\
\hline 41-Ouddorp & 04.0 & $1905-86$ & 40.0 & 240.0 & 19.8 & 13.8 & - & 4096 & $\mathbf{H}$ \\
\hline 42-Flauwers & 09.0 & $05-06-86$ & 40.0 & 270.0 & 13.0 & 13.0 & +++ & 4096 & B3 \\
\hline 43.Den Oase & 11.5 & $07-06-86$ & 55.0 & 080.0 & 12.8 & 12.8 & \pm & 4096 & I \\
\hline 44-Scharendijke & 13.0 & $09-06-86$ & 45.0 & 105.0 & 14.8 & 12.8 & \pm & 4096 & I \\
\hline 45-Scharendijke & 05.5 & $25-06-86$ & 25.0 & 135.0 & 22.0 & 18.5 & - & 4096 & H \\
\hline 46-Ouddorp & 02.1 & $26-06-86$ & 30.0 & 180.0 & 21.0 & 19.0 & - & 3072 & $\mathbf{H}$ \\
\hline 47-Flauwers & 10.4 & $26-06-86$ & 50.0 & 150.0 & 18.1 & 17.5 & +4 & 4096 & B3 \\
\hline 48-Flauwers & 03.5 & $27-06-86$ & 10.0 & 130.0 & 19.0 & 18.0 & ++ & 3072 & D \\
\hline 49-Schelphoek & 10.5 & $27-06-86$ & 46.0 & 090.0 & 22.0 & 18.0 & + & 4096 & $\mathbf{A}$ \\
\hline 50-Springersdiep & 03.5 & $27-06-86$ & 45.0 & 270.0 & & & _ & 4096 & $\mathbf{F}$ \\
\hline 51-Springersdiep & $\mathbf{0 2 . 0}$ & $27-06-86$ & 20.0 & 270.0 & & & - & 4096 & G \\
\hline 52-Zuidbout & 10.4 & $28-06-86$ & 40.0 & 120.0 & 18.8 & 18.2 & + & 4096 & B3 \\
\hline 53-Plompetoren & 06.4 & $18-07-86$ & 45.0 & 210.0 & & & $+H$ & 4096 & C \\
\hline 54-Plompetoren & 12.2 & $18-07-86$ & 45.0 & 180.0 & & & ++ & 3072 & c \\
\hline 55-Flauwers & 10.7 & $1907-86$ & 60.0 & 210.0 & & & $H$ & 3072 & B3 \\
\hline 56-Zoelandbrug & 08.0 & $01-08-86$ & 90.0 & 060.0 & & & _- & 4096 & B3 \\
\hline 57-Den Osse & 07.1 & $03-08-86$ & 61.5 & 037.5 & 20.0 & 18.0 & _- & 4096 & I \\
\hline 58-Zoelandbrug & 04.0 & $03-08-86$ & 45.0 & 240.0 & 19.8 & 18.8 & \pm & 3072 & B3 \\
\hline 59-Den Osee & 03.8 & $04-08-86$ & 50.0 & 360.0 & 18.5 & 18.5 & - & 3072 & $\mathbf{H}$ \\
\hline 60-Den Osse & 03.0 & $04-08-86$ & 30.0 & 330.0 & 20.0 & 20.0 & $\overline{+}$ & 2048 & $\mathbf{J}$ \\
\hline 61-Fiauwers & 11.9 & $05-08-86$ & 35.0 & 225.0 & 18.5 & 18.5 & + & 4096 & B3 \\
\hline 62-Zierikzee & 11.7 & $06-08-86$ & 20.0 & 240.0 & 19.2 & 18.8 & + & 3072 & B3 \\
\hline 63-Springersdiep & 04.4 & $06-08-86$ & 20.0 & 300.0 & 19.6 & 18.6 & \pm & 4096 & $\mathbf{F}$ \\
\hline 64-Burghsluis & 08.3 & 08-08-86 & 50.0 & 120.0 & 18.4 & 18.2 & - & 4096 & $\mathbf{A}$ \\
\hline 65-Flauwers & 02.0 & $17-08-86$ & 30.0 & 050.0 & 19.0 & 18.5 & + & 3072 & D \\
\hline 66-Flauwers & 05.8 & $18-08.86$ & 25.0 & 240.0 & 18.4 & 18.3 & + & 4096 & B3 \\
\hline 67-Nieuwe Sluis & 09.5 & $24-08-86$ & 48.0 & 090.0 & 18.2 & 17.7 & + & 3072 & B3 \\
\hline 68-Plompetoren & 02.2 & $24-08-86$ & 20.0 & 120.0 & 17.1 & & ++4 & 3072 & D \\
\hline 69-Scharendijke & 11.0 & $25-08-86$ & 45.0 & 320.0 & 18.5 & 17.4 & \pm & 3072 & 1 \\
\hline 70-Scharendijke & 04.0 & $26-08-86$ & 20.0 & 350.0 & 17.2 & 17.2 & \pm & 3072 & H \\
\hline 71-Flauwers & 10.6 & $07-09-86$ & 30.0 & 190.0 & 15.2 & 15.2 & + & 4096 & B3 \\
\hline 72-Nieuwe Sluis & 02.5 & $07-09-86$ & 10.0 & 340.0 & 15.3 & 15.2 & +4 & 2048 & $\vec{D}$ \\
\hline 73-Zijpe & 08.6 & $08-09-86$ & 45.0 & 120.0 & 15.0 & 14.8 & \pm & 4096 & B2 \\
\hline 74-Zuidbout & 02.7 & $08-09-86$ & 35.0 & 170.0 & 15.2 & 15.2 & ++4 & 2048 & D \\
\hline 75-Schelphoek & 13.3 & $09-09-86$ & 40.0 & 195.0 & 16.6 & 15.2 & + & 3072 & $\mathbf{A}$ \\
\hline 76-Flauwers & 10.8 & $11-10-86$ & 20.0 & 230.0 & 14.5 & i4.5 & + & 4096 & B3 \\
\hline 77-Scharendijke & 09.5 & $13-10-86$ & 30.0 & 350.0 & 15.7 & 14.3 & + & 3072 & $I$ \\
\hline 78-Springersdiep & 05.6 & $14-10-86$ & 30.0 & 250.0 & 14.5 & 14.4 & - & 3072 & $\mathbf{F}$ \\
\hline 79-Springersdiep & 02.9 & $14-10-86$ & 10.0 & 250.0 & 14.5 & 14.5 & - & 3072 & $\mathbf{0}$ \\
\hline
\end{tabular}




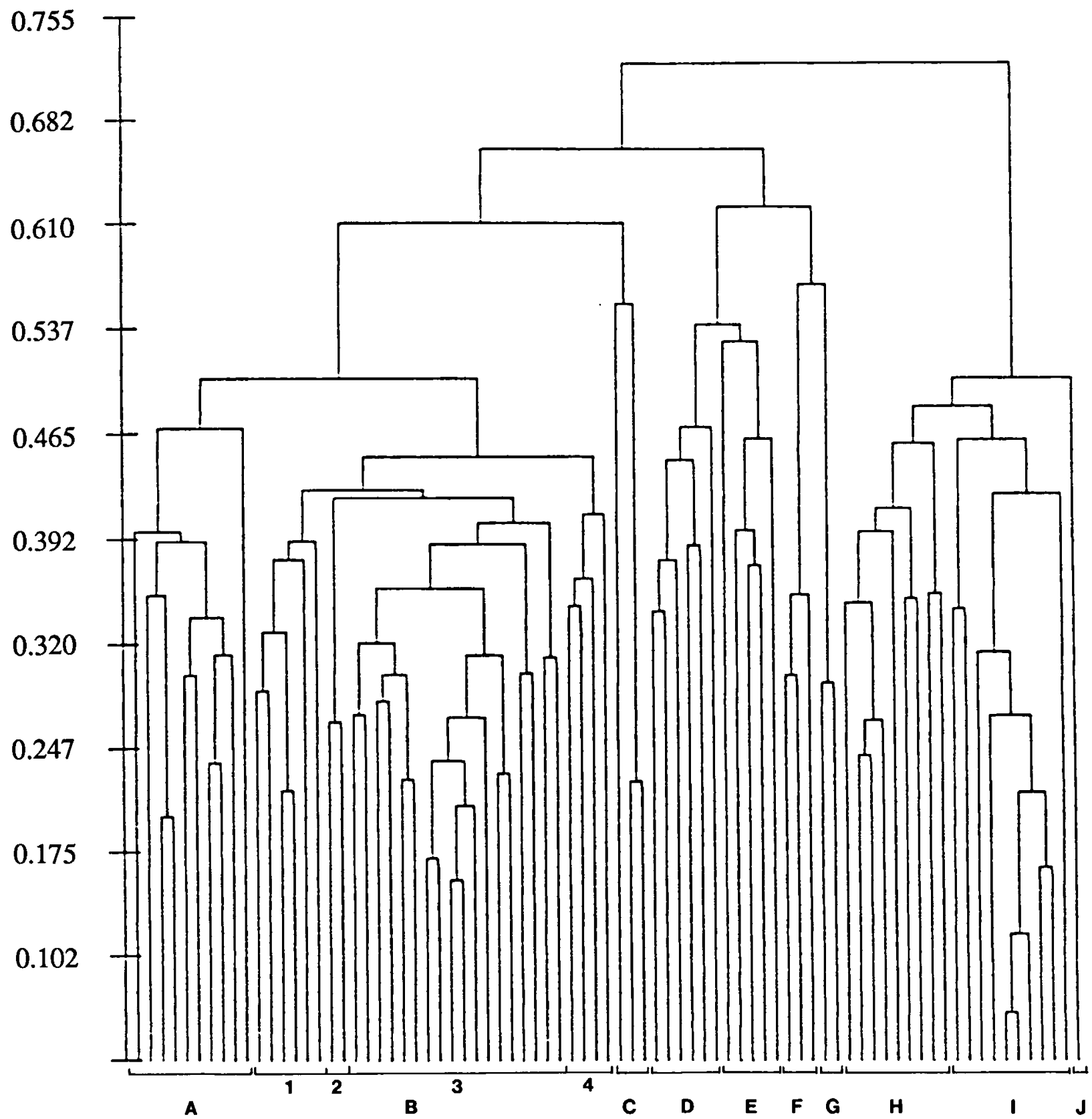

Fig. 6. Dendrogram resulting from the cluster analysis of the data. The clusters distinguished are marked A through J.

After the normal analysis an inverse analysis was performed, using the program SRTORD (Kaandorp, 1986, in prep.). This analysis procures information about the composition of the clusters. Characteristic species are distinguished at a concentration level of $90 \%$ within a community.

\section{Results}

Cluster analysis and inverse analysis

Fig. 6 shows the dendrogram resulting from cluster analysis. Stations sampled at the same localities and depth, during different years and seasons, cluster 
Table 2. Arranged diagram resulting from the inverse analysis for the species occurring in more than one type of environment. The clusters in which a concentration level of $70 \%$ is reached, are marked with '***', clusters found when the level is raised to $90 \%$ are marked with '...' Abbreviations: RA - red alga, GA - green alga, BA - brown alga, H - hydrozoan, B - bryozoan, A - anthozoan, $\mathrm{S}$ - sponge, $\mathrm{T}$ - tunicate, $\mathrm{Sc}$ - scyphozoan, $\mathrm{Bi}$ - bivalve, $\mathrm{C}$ - crustacean, $\mathbf{P}$ - polychaete, $\mathrm{TL}$ - top layer, $\mathrm{ML}$ - middle layer and EL - encrusting layer.

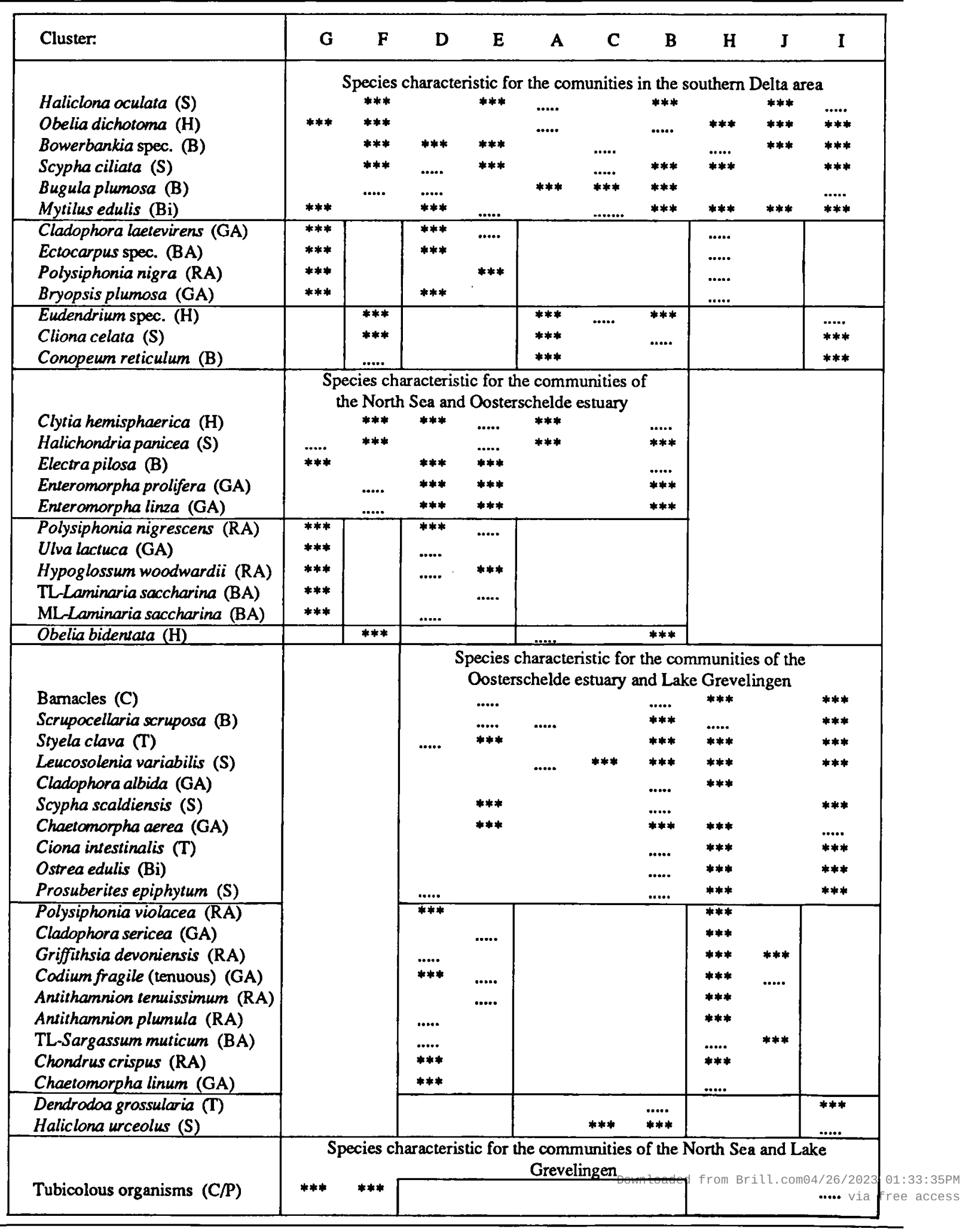


Table 3. Arranged diagram resulting from the inverse analysis for species restricted to one type of environment. For an explanation of the abbreviations and symbols see table 2 .

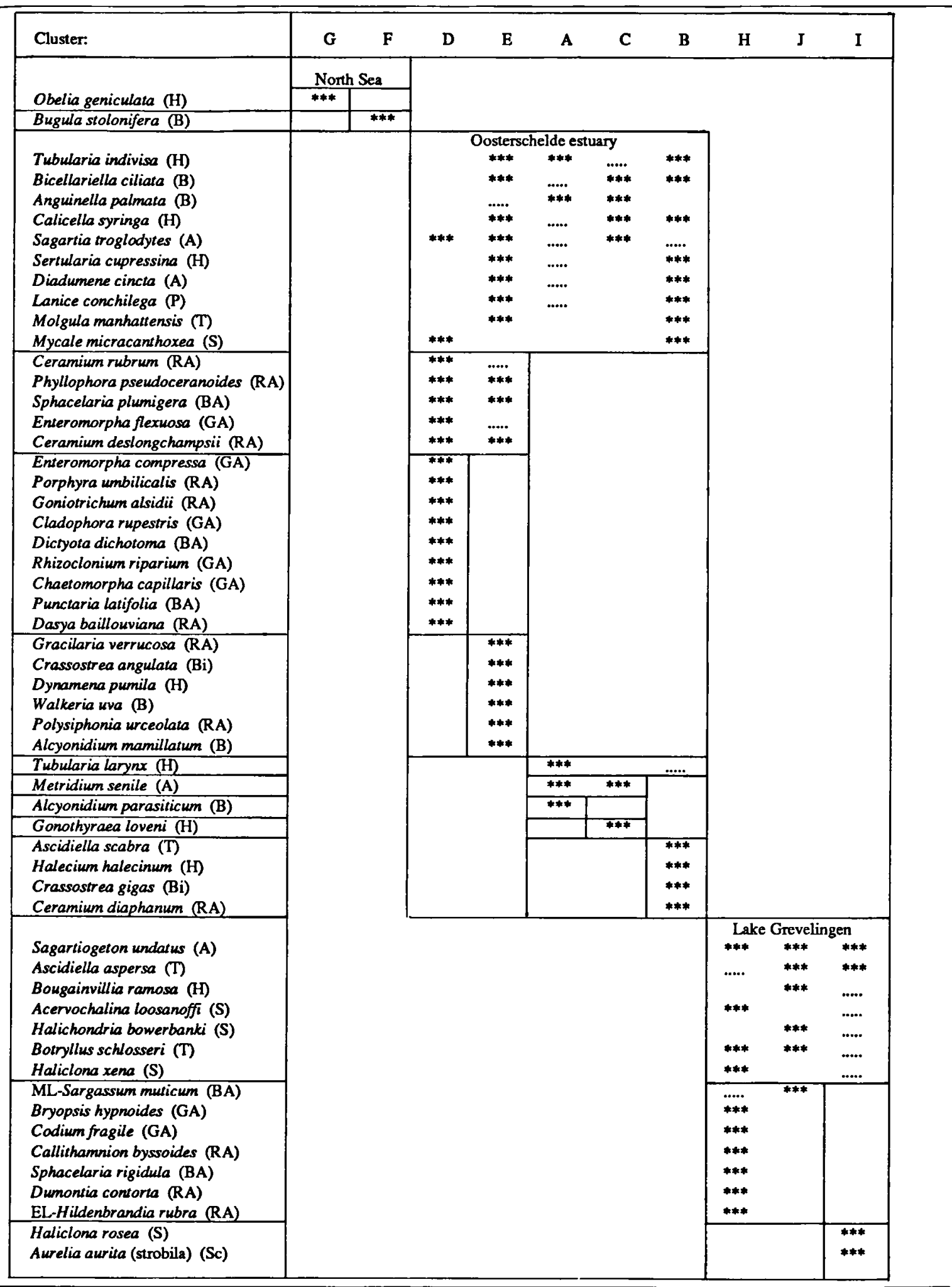


together. Tables 2 and 3 show the arranged diagrams resulting from the inverse analysis. To obtain a better insight into the composition of the communities, the sequence of the clusters of the dendrogram is modified into the arranged diagram. This is permitted because the used linkage method produces different diagrams, dependent on the sequence of the input of data. The resulting distinguishable clusters however, are unaffected by changes in the input. In the diagrams a division into 3 groups is immediately visible: communities restricted to the North Sea, communities restricted to the Oosterschelde estuary and communities restricted to Lake Grevelingen. In table 2 species are listed which occur in two or three of these communities. Only species frequently presented in the different communities are enumerated below.

The sponges Haliclona oculata and Scypha cilia$t a$, the hydrozoan Obelia dichotoma and the bivalve Mytilus edulis are characteristic for all communities in the southern Delta area. The green alga Cladophora laetevirens is characteristic for the communities dominated by algae, while hydrozoans of the genus Eudendrium and the sponge Cliona celata are characteristic for all communities without algae, at greater depths.

The sponge Halichondria panicea and the bryozoan Electra pilosa are characteristic for all communities in the North Sea and Oosterschelde estuary. The communities dominated by algae are characterized by the red algae Polysiphonia nigrescens and Hypoglossum woodwardii, whereas communities lacking algal domination are characterized by the hydrozoan Obelia bidentata.

Barnacles (Balanus balanoides and Elminius modestus), the tunicate Styela clava and the sponge Leucosolenia variabilis are characteristic for the communities in the Oosterschelde estuary and Lake Grevelingen. The communities dominated by algae, are characterized by the red alga Polysiphonia violacea and the tenuous form of the green alga $\mathrm{Co}$ dium fragile.

The North Sea and Lake Grevelingen do not share any characteristic species. The communities all possess tubicolous organisms, but these species belong to different taxa.

There are no characteristic species for the communities of the North Sea.
The hydrozoans Tubularia indivisa and Calicella syringa, the bryozoan Bicellariella ciliata and the anthozoan Diadumene cincta are characteristic species for all communities in the Oosterschelde estuary (table 3). Communities dominated by algae, are characterized by the red algae Ceramium rubrum and Phyllophora pseudoceranoides.

The communities of Lake Grevelingen are characterized by the anthozoan Sagartiogeton undatus and the tunicates Ascidiella aspersa and Botryllus schlosseri.

\section{Environmental parameters}

One of the most important environmental parameters is the total amount of water movement (Riedl, 1971). Water movement was measured as the erosion rate of gypsum blocks. Measurements were carried out in the years 1985 and 1986 . Because work on the storm surge barrier proceeded in this period, the results of 1985 give a better representation of the original current pattern in the Oosterschelde estuary. Water movement consists of 2 components: the first being wave action, the second current velocity. Because wave action depends of prevailing winds, the second component is the more stable. The influence of wave action can almost be neglected at a depth of half a wave length (Van Straaten, 1973). In fig. 7 the erosion values of the gypsum blocks (g.hour ${ }^{-1}$ ) are shown during a lunar day, in depths between 10 and $15 \mathrm{~m}$. The strong reduction of the tidal current in the eastern part of the estuary in 1986 is probably caused by work in the Roompot, the southern gully of the estuary. Because of the east-west orientation of the estuary, a predominant flood-tide current penetrates the estuary through the southern gully, whereas the ebbtide current mainly leaves the estuary through the northern gullies (Kelderman et al., 1984).

The reduction of the current velocity towards the eastern part of the estuary causes a gradient in particle size of deposited material. Cluster analysis yielded a dendrogram with 6 different types of sediments. The result of the inverse analysis is shown in table 4.

Sediment type $\mathrm{I}$ is characterized by a dominance of coarse sand fractions (2.9-1.4 and 1.4-0.6 mm) and fine-grained sand, silt and clay fractions 

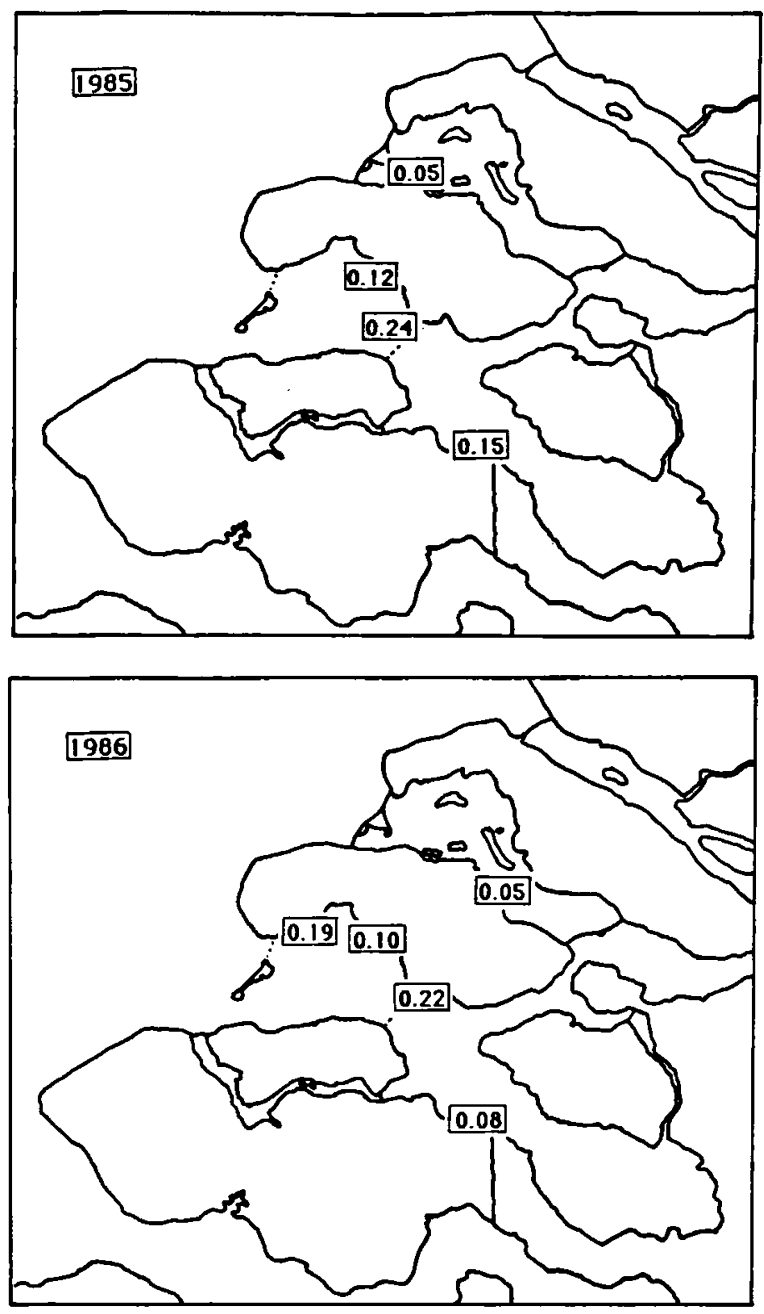

Fig. 7. Erosion values of gypsum blocks (g.hour-1) during a lunar day, between $10-15 \mathrm{~m}$ in 1985 and 1986 .

Table 4. Arranged diagram resulting from the inverse analysis of the sediment data. For an explanation of the symbols see table 2 .

\begin{tabular}{|c|c|c|c|c|c|c|c|}
\hline Fraction: & & Type I & Type II & Type III & Type IV & Type V & Type VI \\
\hline $290-1.40$ & $\operatorname{mm}$ & $* *$ & & $\ldots$ & & & $* *$ \\
\hline $1.40-0.60$ & $\mathrm{~mm}$ & $* *$ & & $\ldots$ & ..... & & $* *$ \\
\hline $0.60-0.30$ & $\mathrm{~mm}$ & ...... & & $\ldots . .$. & $* * *$ & $* * *$ & $* * *$ \\
\hline $0.30-0.15$ & $\mathrm{~mm}$ & & ...... & $* * *$ & $* * *$ & $* * *$ & \\
\hline $0.15-0.09$ & $\mathrm{~mm}$ & $* *$ & $* * *$ & $* * *$ & $* * *$ & & $\ldots . .$. \\
\hline$<0.09$ & $\mathrm{~mm}$ & $* * *$ & $* * *$ & $* * *$ & ..... & & \\
\hline
\end{tabular}

(0.15-0.09 and $<0.09 \mathrm{~mm})$. This type of sediment is found at shallow places in the eastern part of Lake Grevelingen (Dreischor, in depths between 1.0 and $2.5 \mathrm{~m}$ ) and in the Oosterschelde estuary at Flauwers at a depth of $2.0 \mathrm{~m}$.
Sediment type II is characterized by a dominance of the fine-grained sand, silt and clay fractions (0.15-0.09 and $<0.09 \mathrm{~mm}$, respectively). In Lake Grevelingen this type of sediment is found in the north-western part (Ouddorp) at $16.0 \mathrm{~m}$ and in the eastern part (Dreischor) in depths from 5.0 to $\mathbf{1 5 . 0}$ $\mathrm{m}$. In the Oosterschelde estuary this type is found at shallow places $(2.2-3.0 \mathrm{~m})$ at the localities Plompetoren, Schelphoek, Zuidbout and Nieuwe Sluis. This type is also found at the location Zierikzee at a depth of $11.7 \mathrm{~m}$.

Sediment type III is dominated by all fractions smaller than $0.3 \mathrm{~mm}$. This type is found in the western part of Lake Grevelingen (Scharendijke, Den Osse and Ouddorp) from 3.0 to $12.5 \mathrm{~m}$ and in the Oosterschelde estuary at Flauwers $(5.8 \mathrm{~m})$ and in the eastern part (Nieuwe Sluis) at a depth of $9.0 \mathrm{~m}$.

Sediment type IV is characterized by a dominance of the sand fractions $0.6-0.3,0.3-0.15$ and $0.15-0.09 \mathrm{~mm}$. This type is found at the location Springersdiep in the North Sea, shallow places in the western part of lake Grevelingen (Scharendijke and Ouddorp in depths from 3.0 to $3.8 \mathrm{~m}$ ) and the localities on the northern side of the Oosterschelde estuary (Schelphoek, Flauwers, Zeelandbrug and Zijpe), between 8.6 and $30.0 \mathrm{~m}$.

Sediment type $V$ is dominated by the medium and fine sand fractions $(0.6-0.3$ and $0.3-0.15 \mathrm{~mm})$. This sediment type is found at the north-western part of Lake Grevelingen (Ouddorp) at a depth of $1.0 \mathrm{~m}$.

Sediment type VI is dominated by coarse fractions $(2.9-1.4,1.4-0.6$ and $0.6-0.3 \mathrm{~mm})$. This type is found at the north side of the Oosterschelde estuary at the localities Zeelandbrug and Burghsluis (between 8.0-8.3 m).

Towards the eastern part of the Oosterschelde estuary a deposition of fine-grained sediments (type III) takes place in the gullies. Due to the closure of the Volkerak- and Grevelingendam, in the period between 1975 and 1983 in the western part and the northern branch of the eastern part a strong erosion occurred (types IV and VI), causing a deficit in the internal sediment balance, while in the other areas of the eastern part a sediment deposition occurred (Van den Berg, 1986). At shallow places throughout the whole estuary, fine-grained sediments were 


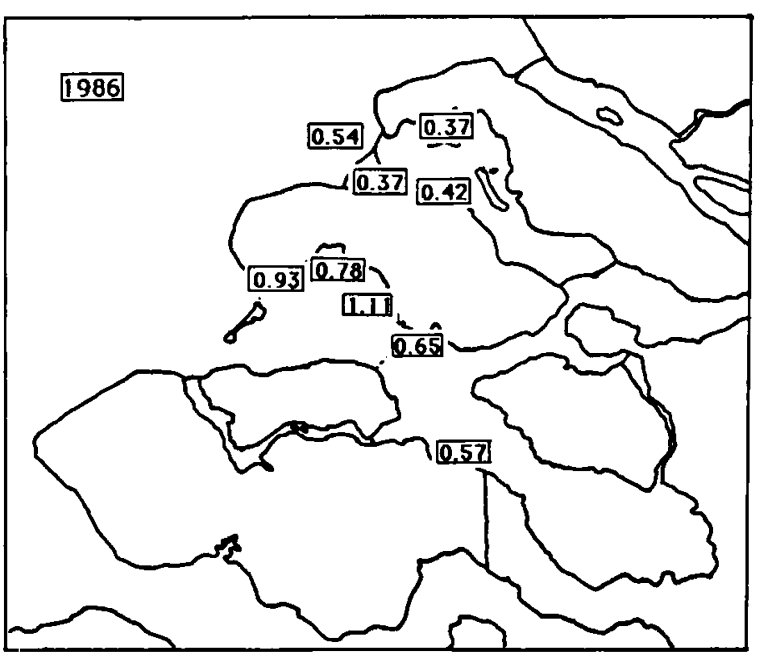

Fig. 8. Vertical extinction coefficients $\left(k\right.$ in $\left.\mathrm{m}^{-1}\right)$ in midwater.

deposited (type II). These sediments consist almost exclusively of marine mud, brought into the estuary by the North Sea (Terwindt, 1967). In lake Grevelingen, after its closure in 1971, tidal currents disappeared and the remaining water movement was mainly wind-induced, causing a redistribution of the fine-grained sediments from shallow places towards the deeper gullies. The eastern part of Lake Grevelingen is more sheltered than the western part. At Dreischor in shallow places type $I$ is present, while at greater depths type II is found. In the western area in shallow places types IV and $\mathrm{V}$ are found, while at greater depths mainly type III is present.

Differences in amount and particle size of suspended matter cause a gradient in the vertical extinction coefficient in midwater (fig. 8). The vertical extinction coefficient determines the depth towards which communities dominated by algae in the middle layer may extend. In the Oosterschelde estuary this depth ranges to $3.5-4.0 \mathrm{~m}$, while in Lake Grevelingen the community occurs to depths of 5.5 to $6.0 \mathrm{~m}$. This implies that the photo-autotrophic zone of sessile algae is limited to a depth at which $10 \%$ of the surface illumination is present.

Since the closure of the Grevelingendam (1964) and Volkerakdam (1969) both the Grevelingen and Oosterschelde estuary were deprived of direct fresh water influences from the rivers Rhine and Meuse.
After closure of the Brouwersdam (1971) the Grevelingen became an independent lake. The Oosterschelde estuary remained under the influence of the North Sea. The discharges of the rivers Rhine and Meuse caused a fluctuation in salinity of the coastal water (minimum $16.7 \mathrm{~g} / 1 \mathrm{Cl}^{-}$, maximum $18.6 \mathrm{~g} / \mathrm{l} \mathrm{Cl}^{-}$, averaged each month during 19721978). Towards the eastern part of the estuary the salinity drops with $2 \mathrm{~g} / \mathrm{Cl}^{-}$(Anonymous, 1980). After the closure of the Brouwersdam the chloride concentration in Lake Grevelingen decreased from $17 \mathrm{~g} / \mathrm{l} \mathrm{Cl}^{-}$(1971) to $12 \mathrm{~g} / 1 \mathrm{Cl}^{-}$(1978). Through the construction of a sluice in the Brouwersdam (1978) and a siphon-sluice in the Grevelingendam (1984) the original salinity is almost restored.

The temperature of the surface of Lake Grevelingen, compared to the Oosterschelde estuary, reached higher values during summer and lower values during winter. Because of the relatively shallow location of the investigated stations, a thermocline is not developed.

\section{The sublittoral communities}

In the dendrogram (fig. 6) 10 clusters are distinguished. The contribution of different taxa, in the different structural layers, to the community composition is listed in table 5 .

Two clusters ( $G$ and $F$, see table 3 ) are restricted to the location in the open North Sea. These coastal communities are found at the location Springersdiep. Community $F$ ranges from 3.5 to $5.6 \mathrm{~m}$. The middle layer mainly consists of the sponge Halichondria panicea. Furthermore, the substrate is entirely covered with tubicolous organisms. The bryozoan Bugula stolonifera is restricted to this community, but there are no characteristic species.

Community $G$ ranges from 2.0 to $2.9 \mathrm{~m}$. Both stations possess a well developed top layer of the brown alga Laminaria saccharina. The middle layer mainly consists of red algae (dominant species: Polysiphonia nigrescens and Hypoglossum woodwardii). The substrate is, like community $\mathrm{F}$, totally covered with tubicolous organisms. The hydrozoan Obelia geniculata is very abundant in this community. The sediments of both communities belong to type IV. The salinity is dependent of 
Table 5. The contribution in $\%$ of different taxa to the community composition.

\begin{tabular}{|c|c|c|c|c|c|c|c|c|c|c|}
\hline Cluster & $\mathbf{G}$ & $\mathbf{F}$ & D & E & A & C & B & H & $\mathbf{J}$ & I \\
\hline Community / variant & $\mathbf{G}$ & $\mathbf{F}$ & D & E & A1 & A2 & B & $\mathrm{H} 1$ & $\mathrm{H} 2$ & I \\
\hline \multicolumn{11}{|l|}{ Top layer: } \\
\hline Brown algae: & 37.1 & 0.0 & 8.3 & 5.5 & 0.0 & 0.0 & 0.0 & 8.5 & 60.0 & 0.0 \\
\hline \multicolumn{11}{|l|}{ Middle layer: } \\
\hline Red algae: & 37.4 & 1.3 & 53.6 & 29.8 & 0.0 & 0.0 & 0.2 & 17.4 & 5.0 & 0.0 \\
\hline Brown algae: & 4.9 & 0.1 & 6.5 & 1.1 & 0.1 & 0.0 & 0.1 & 2.4 & 5.5 & 0.0 \\
\hline Green algae: & 10.8 & 0.6 & 9.9 & 2.3 & 0.1 & 0.0 & 0.6 & 17.1 & 1.1 & 0.1 \\
\hline Anthozoans: & 0.1 & 2.1 & 4.4 & 8.1 & 50.1 & 67.5 & 14.9 & 5.2 & 7.0 & 7.1 \\
\hline Tunicates: & 0.0 & 0.0 & 3.1 & 4.5 & 0.0 & 0.0 & 11.0 & 14.3 & 9.5 & 17.7 \\
\hline Bryozoans: & 23.3 & 1.7 & 17.5 & 12.3 & 2.8 & 1.7 & 8.9 & 0.3 & 0.3 & 1.2 \\
\hline Hydrozoans: & 4.9 & 4.7 & 1.4 & 2.6 & 6.2 & 2.0 & 10.9 & 1.9 & 3.3 & 2.6 \\
\hline Sponges: & 10.0 & 37.8 & 1.1 & 8.9 & 23.2 & 5.9 & 26.3 & 4.3 & 9.8 & 10.5 \\
\hline Bivalves: & 0.3 & 0.1 & 3.0 & 0.2 & 0.2 & 0.2 & 2.9 & 7.2 & 0.5 & 6.2 \\
\hline Crustaceans: & 0.1 & 0.3 & 2.3 & 7.6 & 0.3 & 0.2 & 3.4 & 16.6 & 0.0 & 27.1 \\
\hline Polychaetes: & 0.0 & 0.0 & 0.1 & 1.7 & 1.4 & 0.3 & 2.9 & 0.0 & 0.0 & 0.0 \\
\hline Scyphozoans: & 0.0 & 0.0 & 0.0 & 0.0 & 0.0 & 0.0 & 0.0 & 0.0 & 0.0 & 0.2 \\
\hline Tubiculous organisms: & 81.5 & 59.3 & 3.5 & 0.1 & 1.0 & 0.0 & 0.6 & 2.3 & 5.0 & 11.6 \\
\hline \multicolumn{11}{|l|}{ Encrusting layer: } \\
\hline Red algae: & 0.0 & 0.0 & 0.0 & 0.0 & 0.0 & 0.0 & 0.0 & 0.1 & 0.0 & 0.0 \\
\hline Bryozoans: & 0.0 & 0.1 & 0.0 & 0.0 & 0.2 & 0.0 & 0.0 & 0.0 & 0.0 & 0.0 \\
\hline Bare substrate / silt: & 0.0 & 0.0 & 33.1 & 26.8 & 16.4 & 25.6 & 30.8 & 29.4 & 47.5 & 28.4 \\
\hline
\end{tabular}

the discharge of fresh water by the main rivers in the area.

Communities $\mathrm{H}$, I and $\mathrm{J}$ are restricted to the tideless Lake Grevelingen. These communities are characterized by the anthozoan Sagartiogeton undatus and the tunicates Ascidiella aspersa and Botryllus schlosseri. The communities $\mathrm{H}$ and $\mathrm{J}$ range from 3.0 to $6.0 \mathrm{~m}$ and are found at all investigated localities. On account of characteristic and dominant species cluster $\mathbf{J}$ must be considered as a variant of community $\mathrm{H}$. Community $\mathrm{H}$ (variant $\mathrm{H} 1$ ) is characterized by a top layer of the brown alga Sargassum muticum. The middle layer is mainly formed by red algae (characteristic species: $\mathrm{Cal}$ lithamnion byssoides and Dumontia contorta), green algae (characteristic species: Codium fragile and Bryopsis hypnoides), tunicates (dominant species: Ciona intestinalis) and barnacles. The red alga Hildenbrandia rubra is found in the encrusting layer, but is very rare. In the eastern part of the lake the sediments of these variants belong to type II and in the western part to types III and IV. The main difference between variant $\mathrm{H} 1$ and $\mathrm{H} 2$ (cluster $\mathrm{J}$ ) is that $\mathrm{H} 2$ possesses a very dense canopy of Sargassum muticum. The quadrats of this variant were sampled in the upper border of the community. The well developed top layer causes a poor development of algae in the middle layer. Sessile animals on the other hand, independent of submarine daylight, are even more abundant in variant $\mathrm{H} 2$ than in $\mathrm{H} 1$.

Community I (fig. 9) is found at greater depths, ranging from 7.1 to $15.0 \mathrm{~m}$. The community lacks a top- and encrusting layer. The middle layer lacks algae as well, and is mainly formed by tunicates (dominant species: Ciona intestinalis and Styela clava), sponges, barnacles and tubicolous organisms. There are no species characteristic for this community. The sponge Haliclona rosea is restrict- 


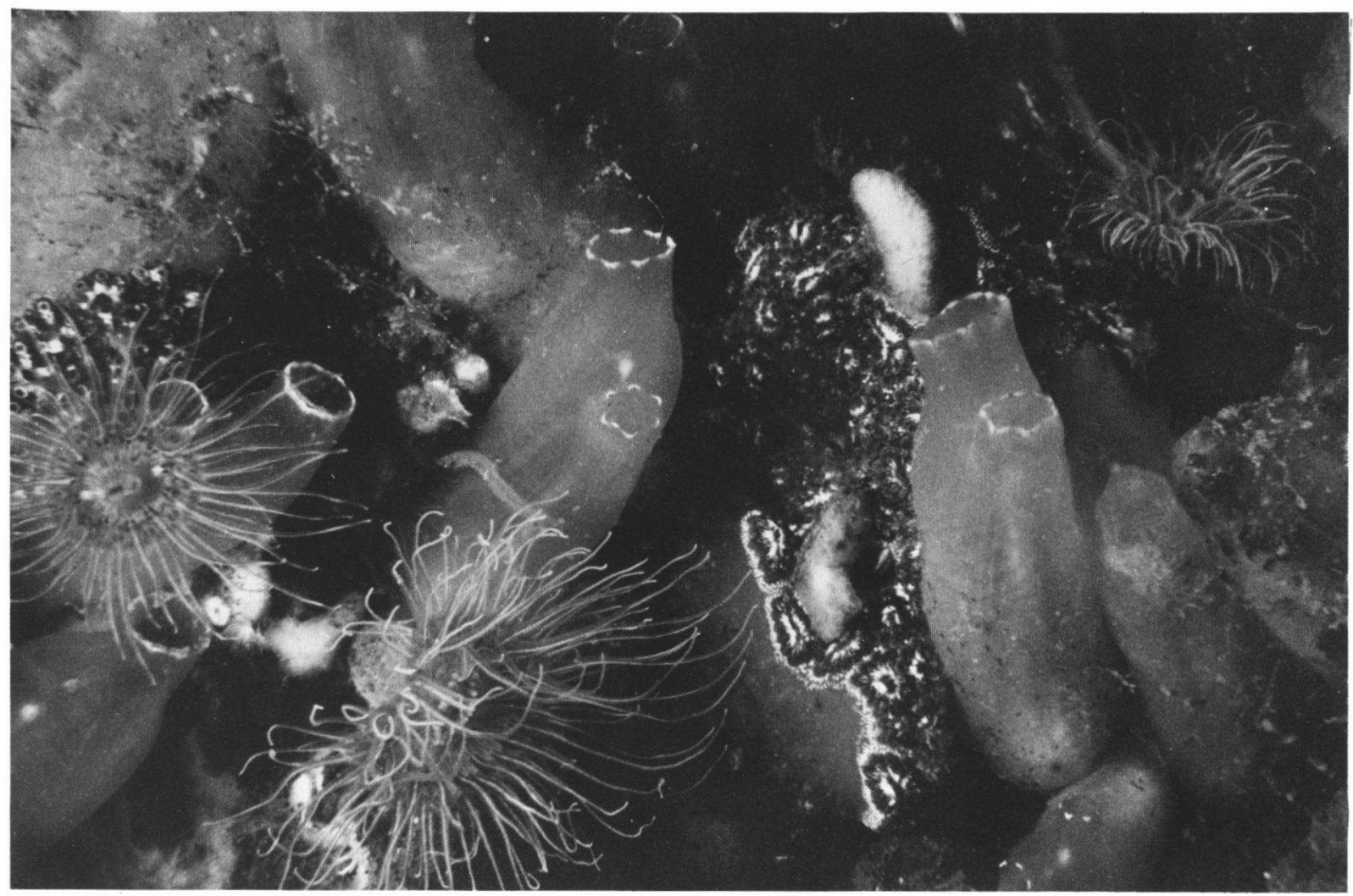

Fig. 9. Community I at Den Osse. In this community the anthozoan Sagartiogeton undatus and the tunicates Ciona intestinalis, Ascidiella aspersa and Botryllus schlosseri are present (photograph: Lisanne Aerts).

ed to this community, but is very rare. In the eastern part of the lake the sediments of this community belong to type II and in the western part to type III.

The remaining 5 clusters are restricted to the Oosterschelde estuary. Two of them (D and E) are dominated by algae in the middle layer.

Community D is found at the localities Plompetoren, Schelphoek, Flauwers, Zuidbout and Nieuwe Sluis, between 2.0 and $3.5 \mathrm{~m}$. At one station a top layer of Sargassum muticum is found. The middle layer is mainly formed by red algae (dominant species: Ceramium rubrum and Polysiphonia nigrescens; characteristic species: Goniotrichum aldisii; unique species: Dasya baillouviana) and bryozoans (Electra pilosa is dominant, growing on algae). An encrusting layer is missing. A great part of the substrate is bare and covered with silt (sediment type II).
Community $\mathbf{E}$ is founded at the localities Zierikzee, Zuidbout, Nieuwe Sluis and Sas van Goes, ranging in depths from 2.7 to $4.0 \mathrm{~m}$. At the location Zierikzee a dense top layer is formed by Laminaria saccharina. The middle layer is, like community $\mathrm{D}$, mainly formed by red algae (dominant species: Ceramium rubrum, Phyllophora pseudoceranoides and Hypoglossum woodwardii; characteristic species: Gracilaria verrucosa) and bryozoans (dominant species: Electra pilosa; unique species: Walkeria uva). The community lacks an encrusting layer and the substrate is also covered with silt (sediment type II). Compared to community D, the middle layer of community $\mathrm{E}$ is less dominated by algae, but the sponge Halichondria panicea and the anthozoan Diadumene cincta are more abundant. The amount of water movement at both communities is strongly dependent of the prevailing weather conditions. 


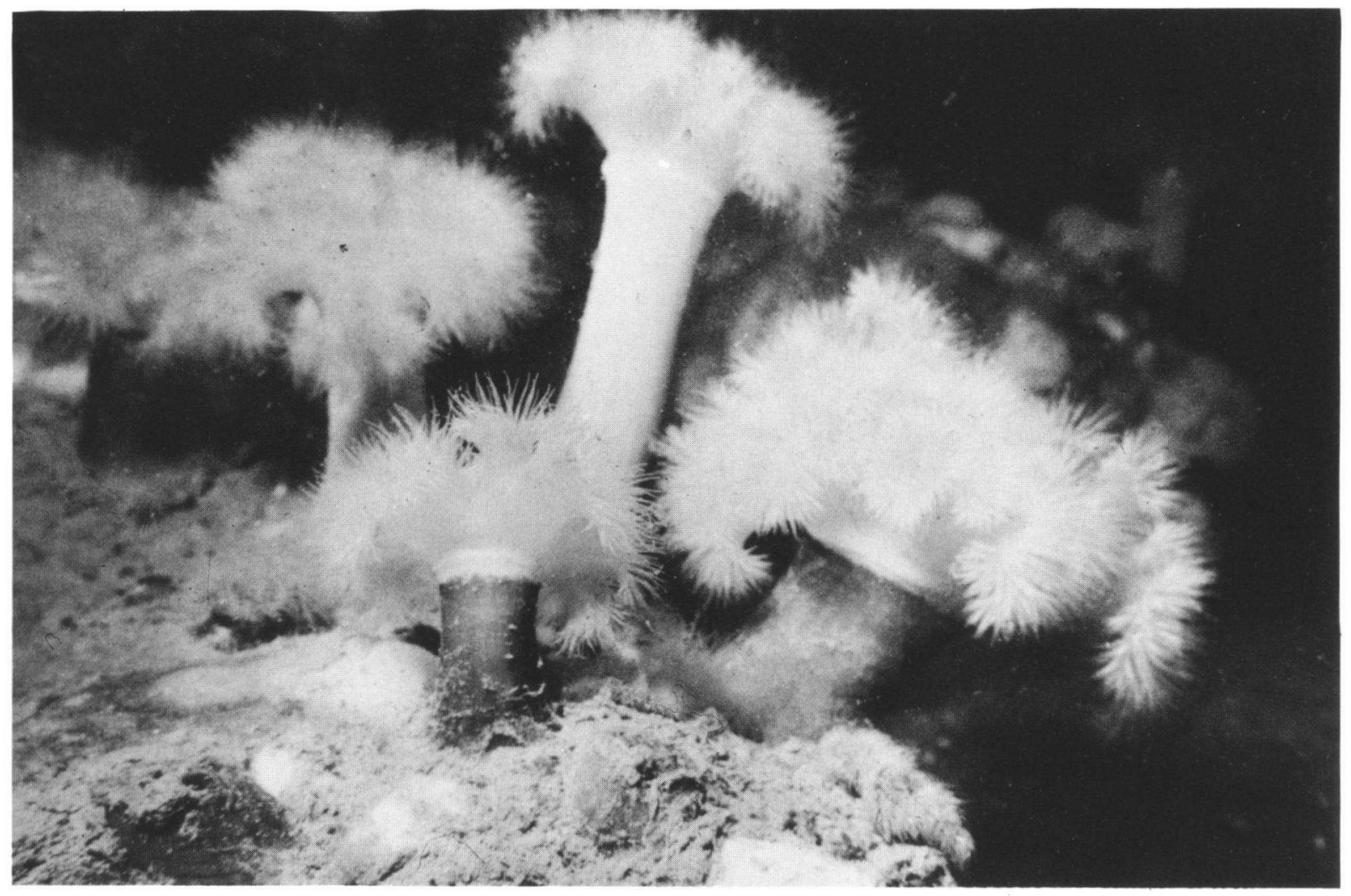

Fig. 10. Community A at Plompetoren (variant A2). Dominant and characteristic species: the anthozoan Metridium senile (photograph Metha and Bob Lambrechts).

The other three clusters, A, B and C, are also found in the Oosterschelde estuary, but at greater depths than communities D and E.

Communities A and C (fig. 10) are found in the mouth of the estuary at the localities Burghsluis, Plompetoren, Schelphoek and Wissenkerke, between 4.0 and $16.5 \mathrm{~m}$. Both communities lack a top layer and algae in the middle layer. The middle layer of both communities is mainly formed by anthozoans (dominant and characteristic species: Metridium senile) and sponges (dominant species: Halichondria panicea). On the basis of community structure, characteristic and dominant species, clusters $\mathrm{A}$ and $\mathrm{C}$ must be considered as two variants of one community (A). Variant Al (cluster A) is more diverse, but in variant A2 (cluster $\mathrm{C}$ ) the characteristic species Metridium senile is more abundant. In variant $\mathrm{Al}$ some small colonies are found of the encrusting bryozoan Conopeum reti- culum, but most of the substrate is bare. The sediment belongs to the types IV and VI. The community is exposed to strong tidal currents and there is a supply of North Sea water with a relatively high salinity and a variety of planktonic species.

Finally, cluster B is found eastward in the estuary at all localities between 3.8 and $16.1 \mathrm{~m}$ (fig. 11). A top layer is absent. In the middle layer algae are of minor importance, it is mainly formed by sponges (dominant species: Halichondria panicea), anthozoans (dominant species: Diadumene cincta), tunicates (dominant species: the introduced Styela clava), hydrozoans (dominant and characteristic species: Halecium halecinum) and bryozoans (dominant species: Electra pilosa). The alien bivalve Crassostrea gigas is restricted to this community. An encrusting layer is missing, most of the substrate is covered with sediment. Towards the eastern part is a decline in water movement, which 


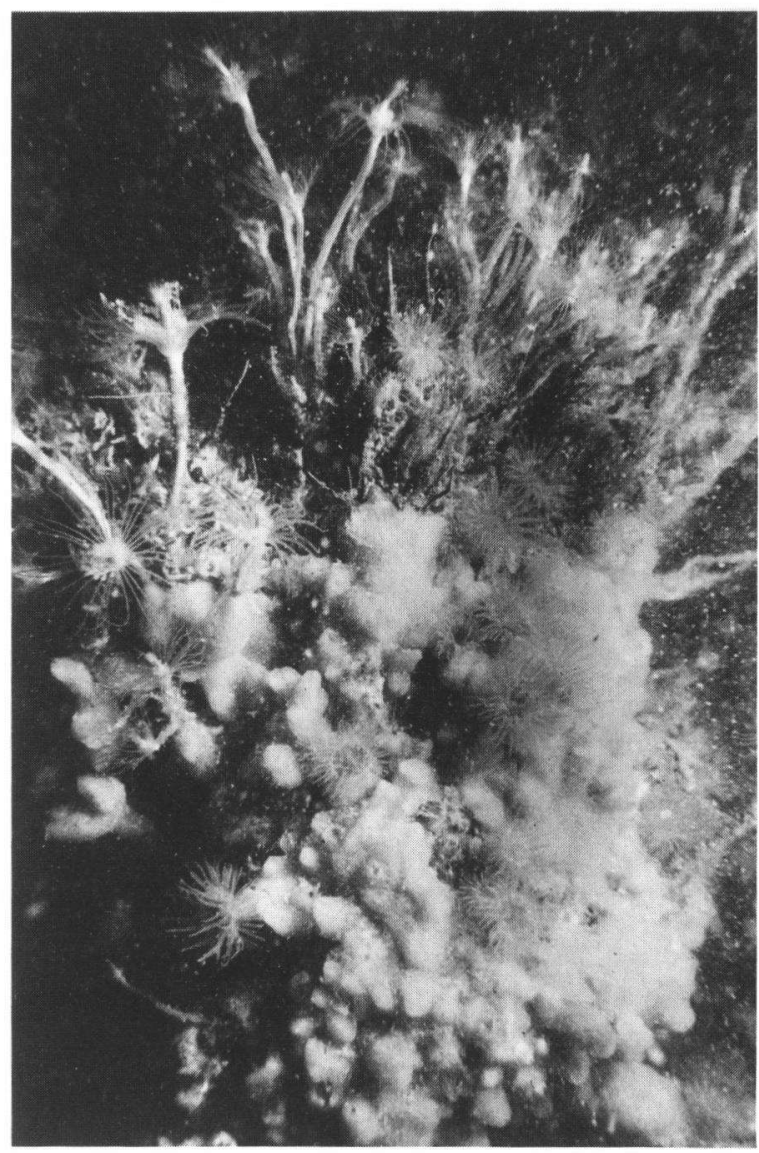

Fig. 11. Community B at Wemeldinge (variant B3). In this community the sponge Halichondria panicea, the hydrozoan Tubularia indivisa and the anthozoan Diadumene cincta are present (photograph: Metha and Bob Lambrechts).

causes a gradient in the sediments from type VI in the western part to type III in the eastern part. Salinity is lower in the eastern part, compared to the mouth of the estuary. It is possible to subdivide this community into four variants on account of species domination. These variants display a regional distribution.

- Variant B2 is restricted to the north-eastern part of the estuary at the location Zijpe, between depths of 5.0 and $8.6 \mathrm{~m}$. Dominant species are Halichondria panicea and Crassostrea gigas. There is very little bare substrate and hardly any sediment.

- Variant B3 is the most common variant in the central part of the estuary and is found between 4.0 and $13.0 \mathrm{~m}$. Dominant species are the hydro- zoans Halecium halecinum and Obelia dichotoma. - Variant B1 is concentrated in the eastern part of the estuary, ranging from 3.8 to $11.7 \mathrm{~m}$. The amount of sediment on the substrate increases compared to the variants B2 and B3. The variant is characterized by a high abundance of Electra pilosa, while Halichondria panicea is rare.

- Variant B4 is found at the localities Zierikzee, Zuidbout, Stavenisse and Katshoek between 9.3 and $16.1 \mathrm{~m}$. Nearly half of the substrate is bare and covered with silt. A dominant species is the tubicolous polychaete Lanice conchilega. Species with a low abundance are Diadumene cincta and Styela clava.

\section{Conclusions}

The communities are determined by their geographical position in the area. The nature, orientation and slope of the artificial substrate seem to be of minor importance. During a semi-quantitative investigation in 1979 (Sandee et al., 1980) it was found that Metridium senile was characteristic for the estuary to the west of the Zeelandbrug (location 6), while Styela clava is characteristic for the localities in the eastern part of the estuary. Recent distribution of communities A and B shows a displacement of community A towards the west. Probably this is caused by a decrease of the total amount of water movement due to the engineering works of the "Delta Plan".

The use of quadrat sampling techniques and the processing of the data by computer leads to reproduceable results. Stations sampled at the same localities and depth, during different years and seasons, cluster together (fig. 6). Correction for the seasonal variation of the communities may not be necessary; at least sampling is possible between April and October. Three to four quadrats (30.7$41.0 \mathrm{dm}^{2}$ ) appear to be sufficient for a representative sample of the communities in the southern Delta area (figs. 3, 4 and 5).

\section{Discussion}

In the southern Delta area 8 different sublittoral communities on hard substrates are described. 


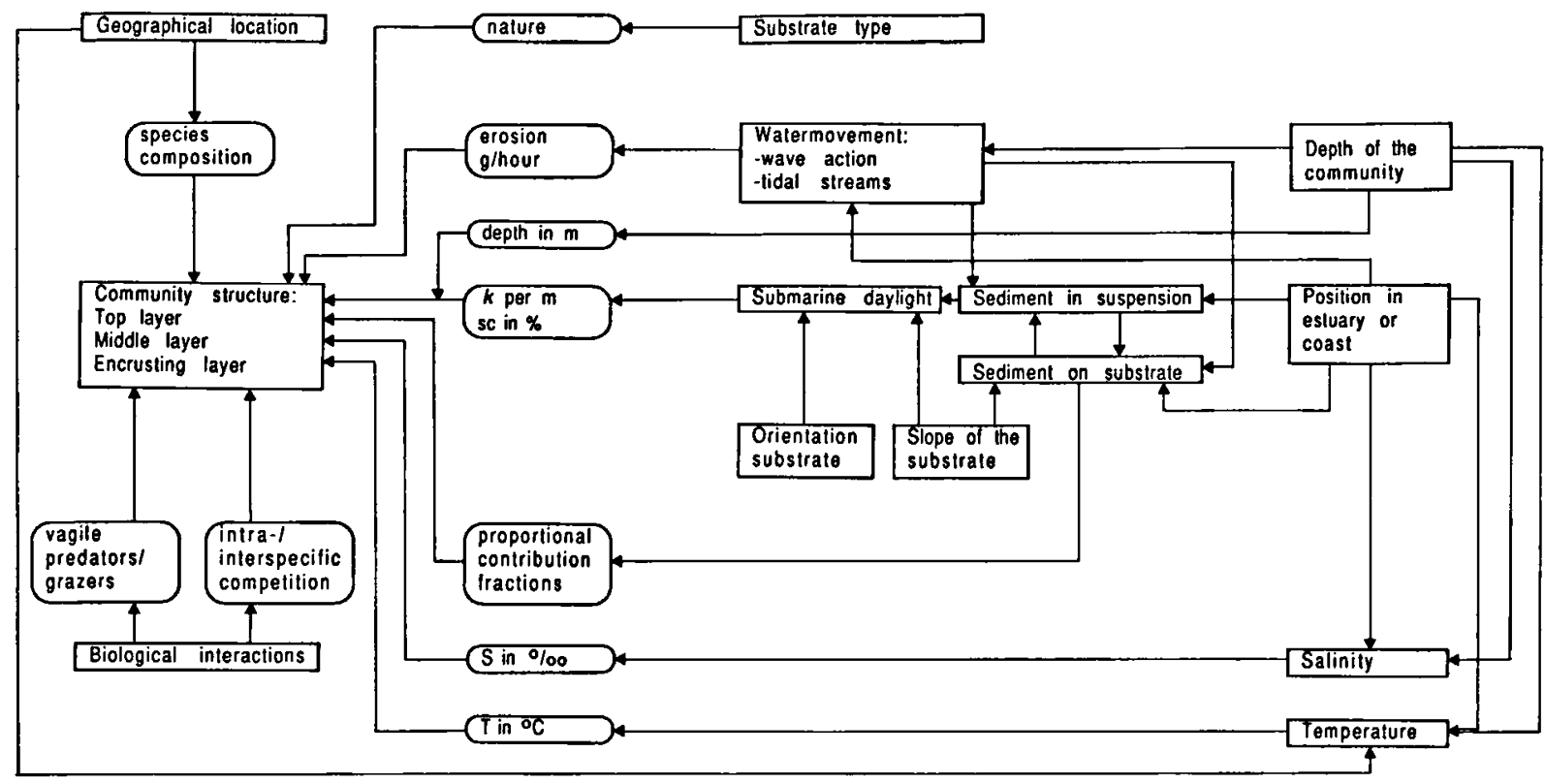

Fig. 12. Interrelationships between biotic and abiotic characteristics in various hard substrate communities. The main components of the environment are placed in rectangles; in ovals the direct or indirect measurements of important parameters are listed.

Three of them can be subdivided into variants. Four communities are dominated by algae in the middle layer. All of these may develop a top layer of brown algae. In the North Sea this layer is formed by Laminaria saccharina, although on more sheltered localities Sargassum muticum is present (personal observations). In the Oosterschelde estuary a top layer may be formed by both Laminaria saccharina and Sargassum muticum, in lake Grevelingen a top layer is formed by Sargassum muticum only. The presence of Laminaria saccharina suggests a certain amount of water movement, Sargassum muticum, on the other hand, is an alien species in the southern Delta area, especially in sheltered places (Nienhuis, 1985). The communities all lack a well developed encrusting layer. Probably this is caused by the sediment load. The main difference between the communities is found in the composition of the middle structural layer. In Lake Grevelingen the communities are developed in their own way. Semi-quantitative data of the communities of the eastern part of the Grevelingen estuary near Dreischor in 1971 (Waardenburg et al., 1984) indicate that the original community with an algal domination in the middle structural layer (domi- nant species: Ulva lactuca and Polysiphonia nigrescens/Ceramium rubrum) showed great similarity to communities D and E. The original community, lacking this algal domination, (dominant species: Halichondria panicea and Mytilus edulis) showed similarity with community B. Fig. 6 immediately shows that in Lake Grevelingen, since the closure of the estuary, new communities have evolved. This will probably also apply to the communities in the Oosterschelde estuary after completion of the Delta Plan.

In order to deliver a base-line for community studies it is necessary to quantify every species as exactly as possible. It is plausible that some smallsized indicator species will never be abundant. Certain small species, such as bryozoans and hydrozoans, are very sensitive towards changes in their environment. It is also necessary to quantify the environmental parameters as far as possible. Descriptive frameworks of sublittoral habitats and communities are often composed of semi-quantitative data, see for example Hiscock \& Mitchell (1980). Erwin (1983) already discussed the wide variety of methods in sublittoral research. As long as no internationally accepted methodology is available, best 
results and applications can be achieved by a completely quantitative description of both the communities and their habitats. A quantitative method leads to reproduceable results and it becomes possible to create a useful framework. In case a framework is produced first, the description of the communities and their habitats are fitted into this system.

Until now only descriptions of sublittoral communities are available. Recent marine engineering projects in the southern Delta area will cause changes of the environmental parameters in the natural habitat. Case-studies in this area will make it possible to understand and predict the responses of communities to human interference in the marine environment. Correlations between the abiotic parameters and species composition and community structures are shown in fig. 12.

\section{Acknowledgements}

Prof. Dr. J.H. Stock and Dr. R.W.M. van Soest of the Institute of Taxonomic Zoology (Amsterdam) and Mr. R. de Groot are thanked for reviewing the first drafts of the manuscript; Drs. J.A. Kaandorp of the Centre for Mathematics and Computer Science (Amsterdam) for his advice during cluster analysis; Drs. M.A.E. Leloup for the co-operation during the first part of this study; Mr. J.M. Villerius and Miss M. Eland for the accomodation and support during the field work; Dr. R.W.M. van Soest and Dr. W.H. de Weerdt for the identification of some sponges; Miss L. Aerts, Mrs. and Mr. Lambrechts for providing the photographs; Mr. J. Vermeulen for his support and last but not least all diving buddies for the assistance during the diving work. This study was supported by grants from the "Stichting Bouwstenen voor de Dierenbescherming" (Amsterdam) and the "BeijerinckPopping Fonds" (Amsterdam). "Aqua Diving" (Amsterdam) and "De Grevelingen" (Scharendijke) are thanked for their material support.

\section{References}

Anonymous, 1980. Het zoutgehalte in de Oosterschelde na 1985. Driemaandelijks Bericht Deltawerken, 92: 80-84.

Anonymous, 1982. De Nederlandse Delta. In: E.K. Duursma, H. Engel \& J.M. Martens (eds.): 1-511. (Natuur en Techniek, Maastricht).

Bannink, B.A., J.H.M. van der Meulen \& P.H. Nienhuis, 1984. Lake Grevelingen: from an estuary to a saline lake. An introduction. Neth. J. Sea Res., 18: 179-190.
Berg, J.H. van den, 1986. Aspects of sediment- and morphodynamics of subtidal deposits of the Oosterschelde (The Netherlands). Rijkswaterstaat communications, 43: 1-127.

Bianchi, C.N. \& C. Morri, 1985. I Policheti come descrittori della struttura trofica degli ecosistemi marini. Oebalia, 11: 203-214.

Coppejans, E., 1980. Phytosociological studies on Mediterranean algal vegetation: Rocky surfaces of the photophilic infralittoral zone. In: J.H. Price, D.E.G. Irvine \& W.F. Farnham (eds.), The Shore Environment, Vol. 2: Ecosystems. (Syst. Ass. spec. Vol., 17b): 371-393. (Academic Press, London).

Erwin, D.G., 1983. The community concept. In: R. Earl \& D.G. Erwin (eds.), The ecology of the shallow sublittoral benthos: 144-164. (Clarendon Press, Oxford).

Gislen, T., 1930. Epibioses of the Gullmar Fjord II. Kristineberg zool. Stat., Skr. Ser. utgiv. k. Svenska Akad., 4: 1-380, 6 pls.

Hartog, C. den, 1959. The epilithic algal communities occurring along the coast of the Netherlands. Wentia, 1: 1-241.

Hiscock, K. \& S. Hiscock, 1980. Sublittoral plant and animal communities in the area of Roaringwater Bay, South-West Ireland. J. Sherkin Isl., 1: 7-48.

Hiscock, K. \& R. Mitchell, 1980. The description and classification of sublittoral epibenthic ecosystems. In: J.H. Price, D.E.G. Irvine \& W.F. Farnham (eds.), The shore environment, Vol. 2: Ecosystems. (Syst. Ass. Spec. Vol., 17b): 323-370. (Academic Press, London).

Kaandorp, J.A., 1986. Rocky substrate communities of the infralittoral fringe of the Boulonnais coast, NW France: a quantitative survey. Mar. Biol., 92: 255-265.

Kaandorp, J.A., in prep. A selection procedure for different numerical classification methods and the inverse analysis applied in quantitative investigations of marine communities.

Kelderman, P., J. Nieuwenhuize, A.M. Meerman-van de Repe \& J.M. van Liere, 1984. Changes of sediment distribution patterns in Lake Grevelingen, an enclosed estuary in the SW Netherlands. Neth. J. Sea Res., 18: 273-285.

Kluijver, M.J. de, 1986. The influence of the storm surge barrier on the sublittoral hard substrate communities of the Oosterschelde estuary (SW Netherlands). Publ. Ser. Neth. J. Sea Res., 13: 12-13.

Kluijver, M.J. de, M. Bilius, M. Reichert \& M.A.E. Leloup, in prep. Sublittoral hard substrate communities of Roaringwater Bay, SW Ireland: a quantitative survey.

Kluijver, M.J. de \& J.A. Kaandorp, in prep. A method for the quantitative measurement of the exposure of littoral and sublittoral communities to wave action and tidal currents.

Könnecker, G. \& B.F. Keegan, 1983. Littoral and benthic investigations on the west coast of Ireland-XVII. The epibenthic animal associations of Kilkieran Bay. Proc. r. Ir. Acad., 83B: 309-324.

Leemans, A.F. \& K. Geers, 1983. Doorbraak in het Oosterscheldebeleid: 1-212. (Coutinho BV, Muiderberg).

Leewis, R.J. \& H.W. Waardenburg, in prep. The flora and fauna of the sublittoral part of the artificial rocky shores in the South-West Netherlands. 
Nienhuis, P.H., 1980. The epilithic algal vegetation of the SW Netherlands. Nova Hedwigia, 33: 1-94.

Nienhuis, P.H., 1985. Japans Bessenwier. Aanwinst of plaag? In: P.H. Nienhuis (ed.), Het Grevelingenmeer. Van estuarium naar zoutwatermeer: 74-81. (Delta Instituut voor Hydrobiologisch Onderzoek, Yerseke).

Pansini, M., R. Pronzato \& E. Leone, 1977. Area minima in un popolamento di poriferi infralittorali. Atti IX Congresso Soc. Ital. Biol. Mar.: 331-335.

Perkins, E.J., 1974. The biology of estuaries and coastal waters: 1-678. (Academic Press, London, New York).

Riedl, R., 1971. Water movement. In: O. Kinne (ed.), Marine Ecology. A compehensive integrated treatise on oceans and coastal waters: 1085-1156. (Wiley Interscience, London, New York, Sydney and Toronto).

Sandee, A.J.J., P. de Koeyer \& R.H. Bogaards, 1980. Inventarisatie van een aantal sublittorale dier- en plantensoorten van de Oosterschelde in de zomer van 1979. Rapporten Verslagen Delta Inst. Hydrobiol. Onderzoek, 1980-4: 1-114.

Soest, R.W.M. van \& S. Weinberg, 1981. Preliminary quantitative assessment of the marine hard substrate communities of Roaringwater Bay. J. Sherkin Isl., 1(2): 10-26.

Sokal, R.R. \& C.D. Michener, 1958. A statistical method for evaluating systematic relationships. Univ. Kansas Sci. Bull., 38: 1409-1438.

Stephenson, T.A. \& A. Stephenson, 1972. Life between tide- marks on rocky shores: 1-425. (W.H. Freeman \& Co., San Francisco).

Straaten, L.M.J.U. van, 1973. De zee I: Water and waterbeweging. In: A.J. Pannekoek (ed.), Algemene geologie: 411417. (D. Tjeenk Willink BV, Groningen).

Terwindt, J.H.J., 1967. Mud transport in the Dutch Delta Area and along the adjacent coastline. Neth. J. Sea Res., 3: 505-531.

Waardenburg, H.W., A.J.M. Meijer, R.J.L. Philippart \& A.C. van Beek, 1984. The hard bottom biocoenoses and the fish fauna of Lake Grevelingen, and their reactions to changes in the aquatic environment. Wat. Sci. Tech., 16: 677-686.

Weinberg, S., 1978a. The minimal area problem in invertebrate communities of Mediterranean rocky substrata. Mar. Biol., 49: 33-40.

Weinberg, S., 1978b. Mediterranean octocorallian communities and the abiotic environment. Mar. Biol., 49: 41-57.

Weinberg, S., 1979. Some hand-held instruments for the diving ecologist: 1-10, (privately printed).

Weinberg, S., 1981. A comparison of coral reef survey methods. Bijdr. Dierk., 51(2): 199-218.

Wishart, D., 1978. CLUSTAN user manual. Program Library Unit Edinburgh University: 1-175. (Edinburgh).

Received: 29 August 1988

Revised : 23 December 1988 